DIW BERLIN

Discussion

Papers

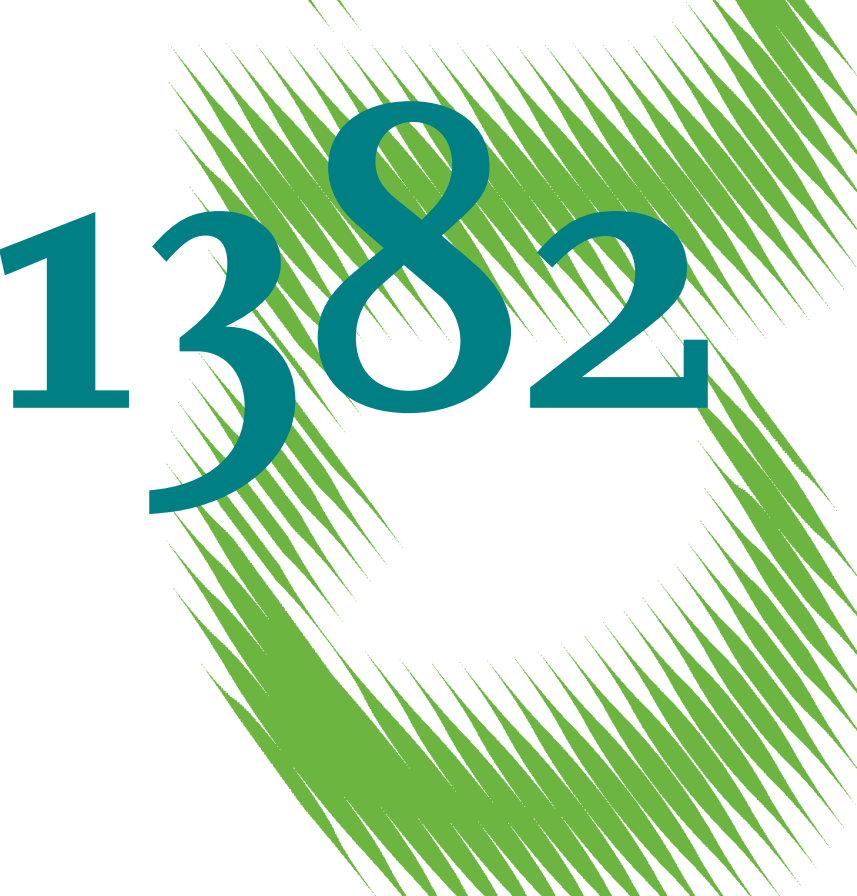

Unconventional Monetary Policy and Money Demand 
Opinions expressed in this paper are those of the author(s) and do not necessarily reflect views of the institute.

IMPRESSUM

(C) DIW Berlin, 2014

DIW Berlin

German Institute for Economic Research

Mohrenstr. 58

10117 Berlin

Tel. $+49(30) 89789-0$

Fax +49 (30) $89789-200$

http://www.diw.de

ISSN print edition $1433-0210$

ISSN electronic edition 1619-4535

Papers can be downloaded free of charge from the DIW Berlin website:

http://www.diw.de/discussionpapers

Discussion Papers of DIW Berlin are indexed in RePEc and SSRN:

http://ideas.repec.org/s/diw/diwwpp.html

http://www.ssrn.com/link/DIW-Berlin-German-Inst-Econ-Res.html 


\title{
Unconventional monetary policy and money demand
}

\section{Christian Dreger and Jürgen Wolters ${ }^{1}$}

\begin{abstract}
This paper investigates the usefulness of the money demand relationship in times of unconventional monetary policies by cointegration methods. In contrast to the bulk of the literature, evidence in favour of a stable long run money demand function is presented both for the US and the euro area. Results are based on standard monetary aggregates, i.e. MZM for the US and M3 in case of the euro area. The recent monetary policy shifts towards unconventional measures did not introduce instability in the relationships. The results suggest that money balances are still useful instruments to conduct monetary policy especially in periods where the nominal interest rates are at the zero lower bounds.
\end{abstract}

Keywords: Unconventional monetary policy, money demand, stability

JEL: C22, C52, E41

\footnotetext{
${ }^{1}$ Dreger: German Institute for Economic Research (DIW Berlin), Mohrenstr. 58, D-10117 Berlin, cdreger@diw.de, Wolters: Freie Universität Berlin, Boltzmannstr. 20, D-14195 Berlin, juergen.wolters@fu-berlin.de.
} 



\section{$1 \quad$ Introduction}

Prior to the financial crisis monetary policy was usually implemented by open market operations to target nominal short term interest rates. Due to price rigidities, central banks implicitly controlled not only the nominal, but also real interest rates over the short and medium run. Real interest rates affect the decisions of enterprises to invest and private households to consume. Central banks can also influence the term structure, if long term interest rates reflect the expected compound yield of revolving short term investments. However, the transmission of monetary policy became impaired since the financial crisis. Due to increased uncertainty commercial banks restricted their credit to firms. To ease monetary conditions and provide additional liquidity, central banks quickly reduced their policy rates. In the following, short term interest rates approached the zero lower bound. The main refinancing rate in the euro area fell from 4.25 in October 2008 to 1 percent in May 2009. The decline has been even more pronounced for the US. The policy rate was reduced from 5.25 percent in July 2007 to 0.15 percent in December 2008 .

With short term interest rates at the zero lower bound, central banks lost the conventional instruments to steer the monetary stance and to provide further stimulus to the real economy. Instead, they had to switch to unconventional policy measures, see Rudebusch (2009) and Fawley and Neely (2013) for recent surveys. While the Federal Reserve raised liquidity mainly by pursuing outright asset purchases of debt and mortgagebacked securities, the ECB responded with additional loans to the banking system and extended the list of eligible collateral banks had to provide. These differences largely 
reflect the institutional frameworks under which both the Fed and the ECB operate, i.e. whether the financial and credit system is dominated by capital markets, as in the US or by banks, as in the euro area.

The implementation of the unconventional measures constitutes a major shift in the conduct of monetary policy. In general, changes in policy rules can have an immediate impact on the decisions of forward looking agents as the latter adapt to the expected effects of the shift in the policy regime. Since the respective equations might become unstable, any policy analysis based on them might lead to biased conclusions. Previous evidence suggests that the Lucas (1976) critique is particularly relevant for monetary policy and financial markets (Clarida, Gali, and Gertler, 2000). However, several studies also found that its quantitative impact is only modest (Estrella and Fuhrer, 2003, Rudebusch, 2005). One interpretation of this finding is that past policy changes are not large enough to affect the behaviour of agents in a critical way (Leeper and Zha, 2003). In addition, forward looking models appear to be less stable than their backward looking counterparts.

The analysis of money balances can provide valuable information on the transmission of monetary policy, especially in periods when interest rates are already at the zero lower bound. However, the usefulness of money as a valid policy instrument is conditional to a robust link between the nominal and real side of the economy, as expressed by the money demand function. The money demand relationship links the monetary development to its fundamental determinants, such as the overall price level, real income and the opportunity costs of holding money. By comparing the actual money stock with its long run equilibrium according to money demand, measures of excess liquidity can be extracted to forecast inflation. 
Many authors argued that money demand has become unstable long before the financial crisis. Such a finding does not necessarily imply a breakdown of the relationship, as certain restrictions may not hold empirically; see Dreger and Wolters (2010, 2014). For example, Hossfeld (2012) emphazied that interest rates should be allowed to enter in an unrestricted way, not as the difference according to the term structure. In fact, we find evidence in favour of a stable long run money demand function, both for the US and the euro area. The equations are remarkable robust even in the most recent periods when quantitative easing policies are applied by the Fed and the ECB. Thus, the empirical relevance of the Lucas critique is minor for money demand even in times of unconventional monetary policy measures. Overall, the results suggest that money stocks provide useful information and should be considered by central banks to conduct monetary policy.

The rest of the paper is organized as follows: Previous findings on money demand are reviewed in Section 2. While the theoretical money demand specification is presented in Section 3, Section 4 is reserved for data issues and the empirical results, especially testing for stability of the preferred equations. Section 5 concludes with some policy implications.

\section{Previous studies on money demand}

Especially at longer horizons, inflation is inherently a monetary phenomenon (Friedman, 1970). As money defines the unit of account, monetary developments are integral to the determination of prices and inflation. Money and measures of excess liquidity can provide signals for the emergence of speculative bubbles in asset markets with risks to 
inflation and the real economy (Bussiere and Fratzscher, 2006). Thus, their evolution should be monitored closely by the central banks.

The M2 aggregate in the US became a primary intermediate target of the Fed monetary policy, as the corresponding money demand function as well as money velocity was rather stable during the 1980s (Feldstein and Stock, 1994). Starting from the early 1990s, the reliability of money stocks as indicators for monetary policy has been increasingly called into question, since M2 money demand became unstable. See Duca and VanHoose (2004) for a review of the debate. Financial innovations including nonmonetary assets such as stock and bond mutual funds led to unpredictable changes in money velocity. Estrella and Mishkin (1997) concluded that whatever their informational content was in earlier periods, monetary aggregates neither the monetary base nor M2 do provide useful information, even not for the prediction of inflation. Woodford (2008) concluded that monetary aggregates should not play a prominent role in the implementation of monetary policy. Given these findings, the Fed downgraded the stock of money in the implementation of monetary policy. Monetary aggregates are just viewed as information variables, just like any other economic indicators, and are analyzed for their information content in assessing future economic conditions (Kahn and Benolkin, 2007).

At the same time, strategies have been proposed to re-establish stability in money demand, such as looking at different money aggregates or at further explanatory variables. Carlson, Hoffman, Keen and Rasche (2000) presented evidence in favour of a stable long run money demand function for MZM through the $1990 \mathrm{~s}^{2}$. Households shifted

\footnotetext{
${ }^{2}$ MZM is Money Zero Maturity. It is equal to M2, less certificates of deposit or other time deposits, plus money market funds. MZM may better represent money readily available for spending and consumption. Money held in time deposits is not immediately accessible at par value.
} 
wealth from time deposits to mutual funds. While such reallocations have been largely induced by depository restructuring, the substitution could be explained in terms of opportunity costs. Broad money holdings are part of the overall portfolio of investors and influenced by asset markets. After augmenting money demand equations with stock and bond market risk measures, Choi and Cook (2007) have been able to derive a rather stable relationship in the periods prior to the financial crisis. In addition, Greiber and Setzer (2007) detected a stable money demand equation for the MZM aggregate by including housing wealth.

In the euro area, the breakdown of standard money demand relations occured after the turn of the century, i.e. several years later than in the $\mathrm{US}^{3}$. Prior to this point, equations for M3 can be firmly established, see Fagan and Henry (1998) and Brand and Cassola (2004). In fact, the euro area monetary aggregate might be more stable than in the US, as financial innovations have been less important and the money demand function results from an aggregation across countries. At the aggregated level idiosyncratic shocks from individual countries might cancel each other (Calza and Sousa, 2003). However, extending the sample to the more recent periods usually deteriorate the finding of a stable money demand; see Gerlach and Svensson (2003). As an alternative, researchers focused on the relationships between the core components instead of the original variables (Neumann and Greiber, 2004) or extended the basic specification with measures of financial uncertainty (Greiber and Lemke, 2005, Carstensen, 2006). By including inflation as part of the opportunity costs, Dreger and Wolters (2010) obtained a stable long run relationship in the period before the financial crisis. Furthermore, household wealth has become more relevant to explain the development of real money balances, see

\footnotetext{
${ }^{3}$ Euro area series prior to 1999 are derived by aggregating national information. The standard data set has been reported by Brandt and Cassola (2004).
} 
Greiber and Setzer (2007) and Beyer (2009). To proxy wealth, house prices are better suited than stock market indices, see Dreger and Wolters (2009).

In contrast to the Federal Reserve, monetary developments are still relevant in the two pillar strategy of the ECB. One pillar is based on the economic analysis of price risks in the short run, as emphasized in the macroeconomic projections exercise. The other pillar, i.e. the Quarterly Monetary Assessment is built on the monetary analysis of risks to price stability in the medium and long run (Fischer, Lenza, Pill and Reichlin, 2009, Hall, Swamy and Tavlas, 2012). Since the turn of the century, actual M3 growth has continuously exceeded its corridor; the latter defined on grounds of potential GDP growth, the inflation target and a secular decline in velocity. During this process, inflation did not accelerate at all, thereby questioning whether a reference path is a reliable tool to interpret the monetary evolution. Hence, the evolution of money lost importance even in the monetary strategy of the ECB.

In a nutshell, money demand equations worked quite well in the US for the aggregate M2 up to the 1990s and in the euro area for M3 up to the 2000s. Since then basic specifications became increasingly unstable and led to several extensions of the relationship. Although some of them have been able to capture the monetary development during the pre-crisis period, monetary aggregates lost relevance in the monetary strategy of central banks, most notably in the US.

\section{$3 \quad$ Specification of money demand}

According to Ericsson (1998), the conventional specification of money demand postulates a long run relationship of the form 


$$
(m-p)_{t}=\delta_{0}+\delta_{1} y_{t}+\delta_{2} w_{t}+\delta_{3} R_{t}+\delta_{4} r_{t}+\delta_{5} o w n_{t}+\delta_{6} \pi_{t}
$$

compare also Dreger and Wolters (2009). Here, $m$ denotes nominal money balances taken in logs, $p$ is the log of the price level, $y$ is log of real income and $w$ is log of real financial wealth. Opportunity costs of holding money are proxied by the nominal long $(R)$ and short $(r)$ term interest rates as well as the annualized inflation rate, i.e. $\pi=4 \Delta p$, in case of quarterly data. In addition, the own yield of money holdings is included (own).

Income is expected to exert a positive effect on nominal and real money balances, as it approximates transaction and precautionary savings motives. Money holdings are also related to a portfolio allocation decision. Surging asset prices may trigger a rise in demand for liquidity due to an increase in household wealth. While the scale effect points to a positive impact of wealth, the substitution effect works in the opposite direction, as higher asset prices make assets more attractive compared to money holdings. As the opportunity costs of money holdings refer to earnings on other financial assets, they should have a negative sign. The inflation rate represents the opportunity costs of holding money instead of real assets. Its inclusion provides also a convenient way to generalize the short run homogeneity restriction between money and prices that may not hold on empirical grounds. Also, adjustment processes in nominal or real terms can be distinguished (Hwang, 1985).

The parameters $\delta_{1}>0$ and $\delta_{2}$ denote the elasticities of money demand with respect to the scale variables, income and wealth. The effects of the return of other financial assets, the own yield and inflation are captured by the semielasticities $\delta_{3}<0, \delta_{4}, \delta_{5}>0$ and $\delta_{6}$ respectively. Due to the ambuigity in the interpretation of wealth effects and inflation 
their signs cannot be specified on theoretical grounds. The same holds for short term interest rates, if the own rate is not included in the equation.

\section{$4 \quad$ Empirical analysis}

\subsection{Data issues}

Using standard specifications in the style of equation (1), the stability of money demmand is examined for the US and the euro area for the 1988Q1-2013Q4 period. Quarterly seasonally adjusted data are used. The selection of the period is motivated by the fact that money demand has been largely stable in the period before, more or less, both in the US and the euro area. Instability should be especially visible in the sample under study. Furthermore, the observation period also includes potential distortions traced to policy shifts in the recent financial crisis. In addition, Alan Greespan became the chairman of the Federal Reserve Board in August 1987.

-Figure 1 about here-

In line with the common practice, nominal money balances are MZM for the US and M3 for the euro area. Income is nominal GDP and financial wealth is proxied by house prices. To derive real money balances $(m-p)$, real wealth $(w)$ and real income $(y)$, the respective series are divided by the GDP deflator $(2010=1)$. Long $(R)$ and short $(r)$ term interest rates are defined by 10-year government bonds and 3-month money market rates, respectively. For the US, the own yield (own) refers to the own rate of the MZM aggregate. As the own yield is not available for the euro area, the 3-month money mar- 
ket rate may be taken as a proxy instead. Inflation $(\pi)$ refers to the annualized quarteron-quarter change of the log of the GDP deflator. The variables used in the analysis are displayed in Figure 1.

Series are from the FRED database of the Federal Reserve Bank of St. Louis for the US and from the ECB monthly bulletin for the euro area ${ }^{4}$. House prices are reported by the Federal Reserve Bank of Dallas (Mack and Martínez-García, 2011). For the US, two impulse dummies (2001Q1 and 2001Q4) are included to capture the burst of the new economy bubble and the terrorist attack in September 11, 2001. They are equal to 1 in the respective quarter and 0 otherwise. For the euro area, impulse dummies refer to 1990Q2 and 2001Q1. While the former is related to the German unification, the latter reflects stock market turbulences. In addition, euro area house prices are not relevant for money demand prior to 2002. However, they capture the permanent shift in velocity since then (Dreger and Wolters, 2009). Hence, wealth is multiplied by a step dummy equal to 1 from 2002Q1 onwards and 0 before. All variables are in logs, except of interest rates, which are percentage points.

\subsection{Cointegration analysis}

Since the variables are nonstationary, a cointegration analysis is the appropriate strategy to proceed ${ }^{5}$. Hence, if a stable money demand relationship can be derived, it should be interpreted in terms of a long run attractor for the development of real money balances. Thus the long run relationships of the relevant variables are examined for the respective

\footnotetext{
${ }^{4}$ Data refer to the actual composition of the euro area. Up to 2006, twelve countries formed the monetary union. In the enlargement process afterwards, several countries have joined the common currency area, but have a very small weight in the aggregate.

${ }^{5}$ Results of unit root tests are available from the authors upon request.
} 
areas. For the US the set of variables comprises real money balances, real income, real wealth, the short and long term interest rate as well as the own rate of holding money. For the euro area no own rate is available, but inflation is added to this set. Dreger and Wolters (2010) argued that the inclusion of this variable is crucial to obtain a stable model, at least in the pre-crisis period ${ }^{6}$. The results on the cointegration ranks are shown in Table 1.

-Table 1 about here-

Two cointegration vectors emerge for the US and three for the euro area. Besides a possible long run money demand relation, the other relationships may be related to meanreverting combinations of opportunity costs, like the spread of long and short term interest rates or the Fisher effect, i.e. a stationary long term real interest rate. As the main interest is on money demand, the focus is on the first vector. It corresponds to the largest eigenvalue, i.e. it shows the largest canonical correlation with a stationary relationship between the variables involved.

\section{-Table 2 about here-}

Reduced rank maximum likelihood estimates of the first cointegration vector without any imposed restrictions are exhibited in Table 2 (Johansen, 1995). To improve readability, the parameters are normalized to the coefficient of real money balances. The feedback coefficients in the lower part of Table 2 reveal the adjustment pattern, i.e. the

\footnotetext{
${ }^{6}$ The inflation rate was also included in the US model, but this extension does not alter the results. In fact, the respective coefficient is largely insignificant in the cointegrating relationships.
} 
impact of deviations from the long run development on the short term fluctuations of all variables of the system.

The long run income elasticity of money demand takes a value of about 2 in case of the US. The wealth variable enters with a negative sign in the money demand equation, i.e. its impact works mainly through portfolio reallocation. The combined elasticity of the activity variables $(y$ and $w)$ is about 1.6. The own rate enters with the correct sign. The long term interest rate clearly captures the opportunity costs of holding money, whereas the short term rate is less important. The feedback coefficient of real money balances is negative and strongly significant. It indicates that real money correctly adjusts to deviations from the long run relations. Other variables appear to be weakly exogenous, more or less. Therefore this long run relation can be interpreted in terms of a money demand equation $^{7}$.

For the euro area the income elasticity is about 1.1. In contrast to the US the impact of real house prices, the proxy for wealth, is positive, i.e. substitution effects do not play a dominant role. The combined elasticity of the activity variables ( $y$ and $w$ ) is about 2 which is quite comparable to the results for the US. The semielasticities of interest rates tend to be smaller in absolute values than their US counterparts. The short term interest rate approximates the effect of the missing own rate, whereas the long term interest rate and the inflation rate capture the opportunity costs of holding money. According to the feedback coefficients, only real money balances react significantly to deviations from the long run, whereas all the other adjustment coefficients are insignificant, i.e. the cor-

\footnotetext{
${ }^{7}$ The results for the US can be confirmed, if the M2 aggregate is used instead of MZM. Nonetheless, the evidence is stronger for MZM. Results for M2 are not reported here, but are available from the authors upon request.
} 
responding variables are weakly exogenous. Thus a money demand function can be firmly established for the euro area.

\subsection{Conditional error correction and stability analysis}

As the main interest is on money demand, the short run dynamics are efficiently investigated in a conditional single equation error correction model explaining the change in the demand for real money balances. In general, this approach can lead to constant coefficients even if a shift is present in the reduced form. Even more important, stability of the relationship can be easier explored in this context. Furthermore, a VAR framework might not be optimal to handle for policymakers, as they have to conduct monetary policy in real time.

According to Stock (1987) the conditional error correction model is estimated by ordinary least squares in one step, where the long run parameters are revealed jointly with the short run dynamics. We choose a specific to general approach: The change of real money balances is explained by a constant the respective impulse dummies and the one period lagged levels of all variables to control for the cointegration property. This specification could be improved by including the contemporaneous change of the inflation rate. The final specifications are shown in Table 3.

-Tables 3 and 4 and Figure 2 about here-

The residuals are well behaved as they are normally distributed, homoscedastic and do not show autocorrelation patterns (Table 4). The RESET test of the functional form 
does not reveal any problems. The coefficients of the one period lagged real money balances are negative with $t$-values of -6.96 for the US and -10.59 for the euro area. According to Hassler and Wolters (2006, Table 1) the corresponding 0.01 critical value is 4.89, meaning that there is overwhelming evidence for cointegration in both cases. The implied long run money demand relationship reads:

United States: $m-p=2.026 y-0.389 w-0.049 R-0.136 r+0.248 o w n$

Euro area: $\quad m-p=1.494 y+0.612 w-0.026 \pi-0.021 R+0.023 r$

These relations are similar to the findings from the cointegrated VAR approach given in Table 2. The mean adjusted error correction terms derived from the above relations are displayed in Figure 2. Both show some persistence, but neither deterministic nor stochastic trends. Positive deviations indicate excess liquidity, i.e. liquidity above the fundamental value according to money demand. From about 2008 until the end of the sample excess liquidity in the US does not seem to be very pronounced in contrast to that of the euro area. While the unconventional policy measures tremendously increased the monetary base, the broader monetary aggregates did not respond in a similar manner, at least for the US.

-Tables 4 and 5 and Figure 3 about here-

Finally it is explored whether the money demand relationships are stable or instability is dominant, for example, due to the financial crises starting in 2007 and the quantitative easing policies of the central banks beginning at the end of 2008. Chow forecast tests 
given in Table 5 do not indicate any instabilities for the period 2007Q1 until 2013Q1. The stability result is broadly confirmed by the Quandt-Andrews tests for an unknown breakpoint. According to the maximum of the $F$-statistics, there is weak evidence for an outlier related to the breakdown of the new economy bubble at the beginning of the century, but it is not traced to the period of the financial crisis. Besides that, the cusum of squares tests do not show signs of instability (Figure 2$)^{8}$.

\section{Conclusion}

This paper investigates the usefulness of the money demand relationship in times of unconventional monetary policies by cointegration methods. In contrast to the bulk of the literature, evidence in favour of a stable long run money demand function is presented both for the US and the euro area. Results are based on standard monetary aggregates, i.e. MZM for the US and M3 in case of the euro area. The recent monetary policy shifts towards unconventional measures did not introduce instability in the relationship. Although the dependency of the parameters on the policy regime might be convincing from a theoretical point of view, the empirical relevance of the Lucas critique can be doubted in case of money demand.

A single equation analysis provides reliable information for the conduct of monetary policy. Despite the fact that this approach is efficient in this analysis, the cointegration evidence is quite similar to the VAR findings. Overall, the results suggest that money balances are still useful instruments to conduct monetary policy especially in periods where the nominal interest rates are at the zero lower bounds.

\footnotetext{
${ }^{8}$ In addition, the recursive regression coefficients exhibit no deviations from the assumption of constant parameters. Results are available upon request.
} 


\section{References}

Beyer A (2009): A stable model for euro area money demand. Revisiting the role of wealth. ECB Working Paper 1111.

Brand C, Cassola (2004): A money demand system for euro area M3. Applied Economics $8,817-838$.

Bussiere M, Fratzscher M (2006): Towards a new early warning system of financial crises, Journal of International Money and Finance 25, 953-973.

Calza A, Sousa J (2003): Why has broad money demand been more stable in the euro area than in other economies? Literature review, ECB Working Paper 261.

Carlson J, Hoffman D, Keen B, Rasche R (2000): Results of a study of the stability of cointegrating relations comprised of broad monetary aggregates. Journal of Monetary Economics 46, 345-383.

Carstensen K (2006): Stock market downswing and the stability of European Monetary Union money demand. Journal of Business and Economic Statistics 24, 395-402.

Choi WG, Cook D (2007): Financial market risk and US money demand. IMF Working Paper WP07/89.

Clarida R, Galí J, Gertler M (2000): Monetary policy rules and macroeconomic stability. Quarterly Journal of Economics 115, 147-180.

Dreger C, Wolters J (2009): M3 velocity and asset prices in the euro area. Empirica 36, 2009, 51-63.

Dreger C, Wolters J (2010): Investigating M3 money demand in the euro area, Journal of International Money and Finance 29, 111-122. 
Dreger C, Wolters J (2014): Money demand and the role of monetary indicators in forecasting euro area inflation, International Journal of Forecasting 30, 303-312.

Duca J, VanHoose D (2004): Recent developments in understanding the demand for money, Journal of Economics and Business 56, 247-272.

Ericsson NR (1998): Empirical modelling of money demand. Empirical Economics, 23, 295-315, reprinted in Lütkepohl H, Wolters J (eds.): Money demand in Europe, Physica 1999, 29-49.

Estrella A, Fuhrer JC (2003): Monetary policy shifts and the stability of monetary policy models. Review of Economics and Statistics 85, 94-104.

Estrella A, Mishkin FS (1997): Is there a role for monetary aggregates in the conduct of monetary policy? Journal of Monetary Economics 40, 279-304.

Fagan G, Henry J (1998): Long run money demand in the EU: Evidence for area-wide aggregates, Empirical Economics 23, 483-506, reprinted in Lütkepohl H, Wolters J (eds.): Money demand in Europe, Physica 1999, 217-240.

Fawley BW, Neely CJ (2013): Four stories of quantitative easing. Federal Reserve Bank of St. Louis Review 95, 51-88.

Feldstein M, Stock JH (1994): The use of a monetary aggregate to target nominal GDP. NBER Working Paper 4304.

Fischer B, Lenza M, Pill H Reichlin L (2009): Monetary analysis and monetary policy in the euro area, 1999-2006, Journal of International Money and Finance 28, 11381164. 
Friedman M (1970): A theoretical framework for monetary analysis. Journal of Political Economy 78, 193-238.

Gerlach S, Svensson LOE (2003): Money and inflation in the euro area: A case for monetary indicators? Journal of Monetary Economics 50, 1649-1672.

Greiber C, Lemke W (2005): Money demand and macroeconomic uncertainty, Deutsche Bundesbank Discussion Paper 26/05.

Greiber C, Setzer R (2007): Money and housing: Evidence for the euro area and the US. Deutsche Bundesbank, Discussion Paper Series 1, Economic Studies 2007-12.

Hall SG, Swamy PA, Tavlas GS (2012): Milton Friedman, the demand for money, and the ECB's monetary policy strategy, Federal Reserve Bank of St. Louis Review, 153186.

Hassler U, Wolters J (2006): Autoregressive distributed lag models and cointegration, AStA Advances in Statistical Analysis 90, 59-74.

Hossfeld O (2010): US money demand, monetary overhang and inflation prediction. INFER Working Paper 2010.4.

Hwang H-S (1985): Test of the adjustment process and linear homogeneity in a stock adjustment model of money demand, Review of Economics and Statistics 67, 689-692. Johansen S (1995): Likelihood based inference in cointegrated vector autoregressive models. Oxford: Oxford University Press.

Johansen S (2002): A small sample correction for the test of cointegration rank in the vector autoregressive model, Econometrica 70, 1929-1961. 
Kahn GA, Benolkin S (2007): The role of money in monetary policy: Why do the Fed and ECB see it so differently? Federal Reserve Bank of Kansas City, Economic Review 03/07, 5-36.

Leeper EM, Zha T (2003): Modest policy interventions. Journal of Monetary Economics $50,1673-1700$.

Lucas RE (1976): Econometric policy evaluation: A critique. Carnegie-Rochester Conference Series on Public Policy 1, 19-46.

Mack A, Martínez-García E (2011): A cross-country quarterly database of real house prices: A methodological note. Globalization and Monetary Policy Institute Working Paper 99, Federal Reserve Bank of Dallas.

Neumann MJM, Greiber K (2004): Inflation and core money growth in the euro area, Deutsche Bundesbank Discussion Paper 36/04.

Rudebusch GD (2005): Assessing the Lucas critique in monetary policy models. Journal of Money, Credit and Banking 37, 245-272.

Rudebusch, GD (2009): The Fed's monetary policy response to the current crisis. Federal Reserve Bank of San Francisco, Economic Letter 2009-17.

Stock JH (1987): Asymptotic properties of least-squares estimators of cointegrating vectors. Econometrica 55, 1035-1056.

Woodford M (2008): How important is money in the conduct of monetary policy? Journal of Money, Credit and Banking 40, 1561-1598. 
Figure 1: Variables in the analysis

\section{United States}

Real moneybalances

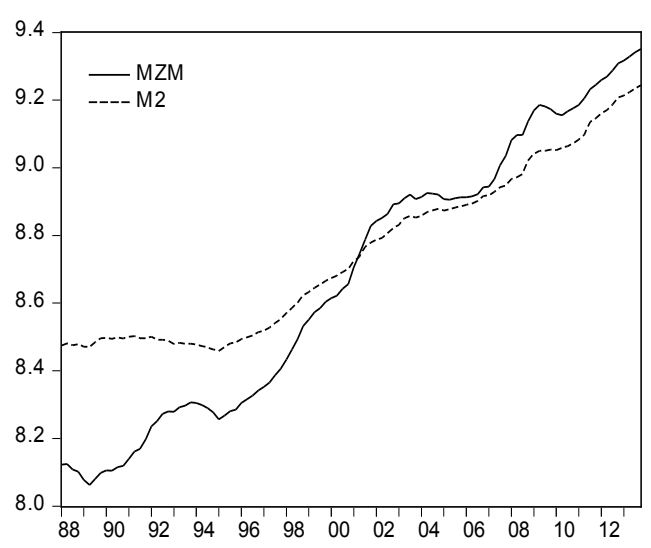

Real house prices

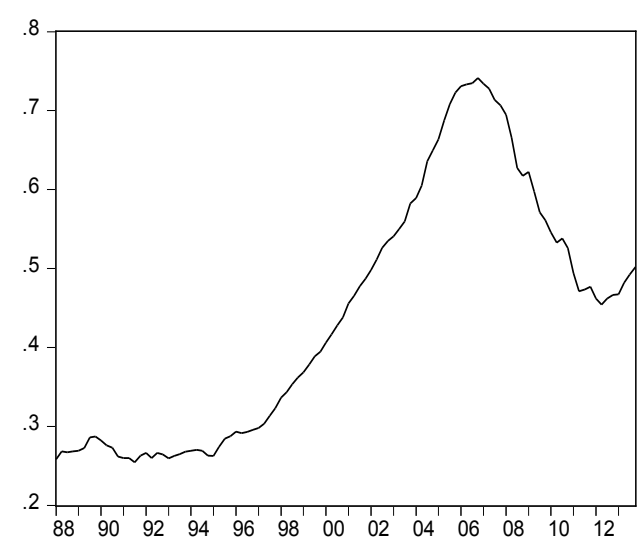

Nominal interest rates

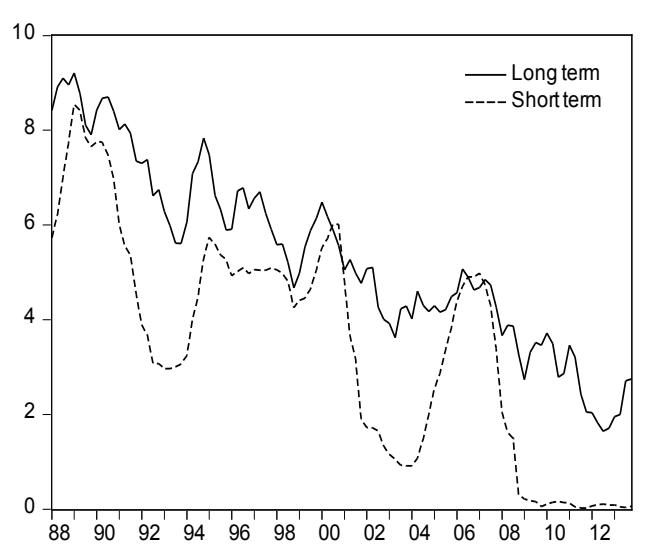

Real income

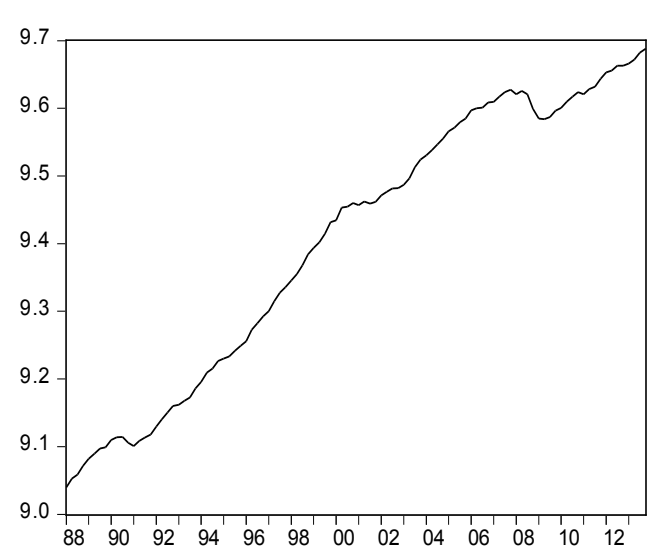

Inflation

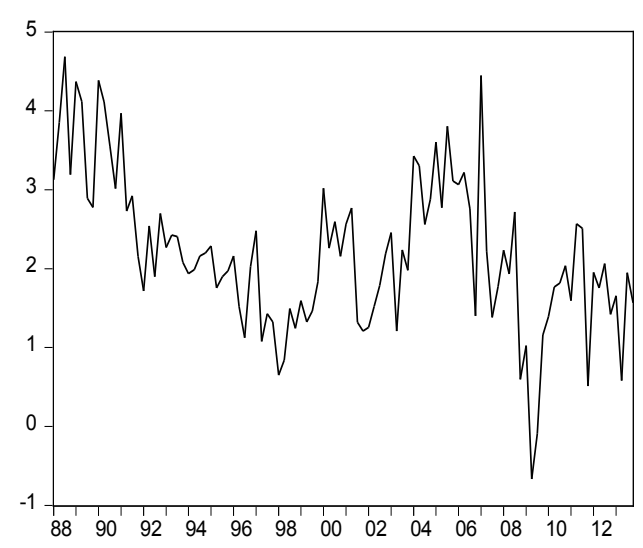

Own rate

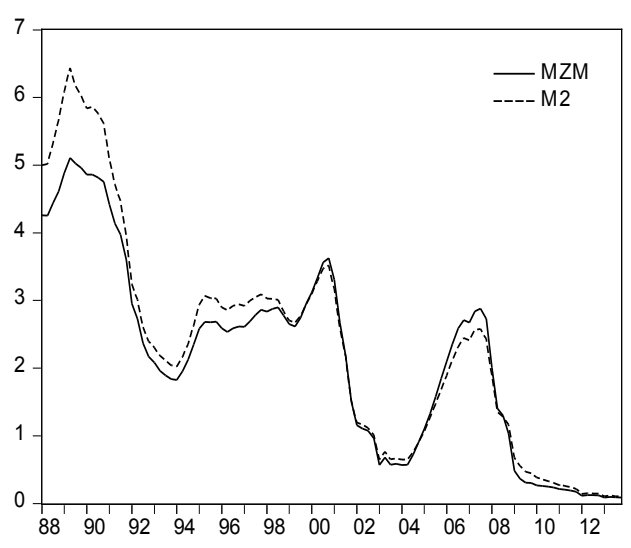


Euro area

Real money balances

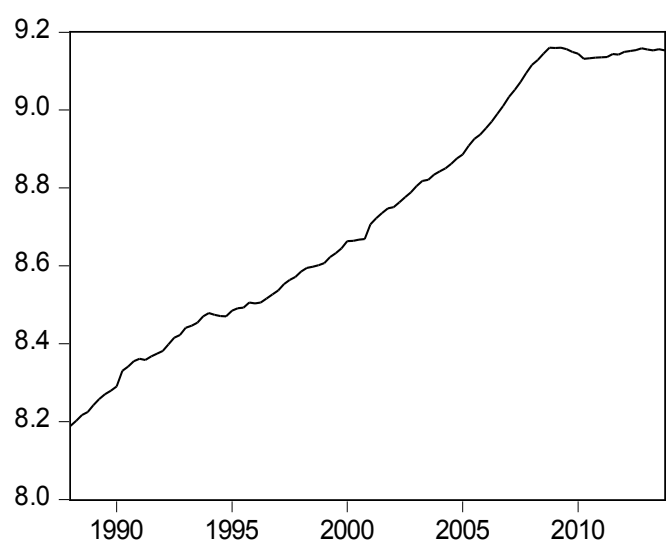

Real house prices

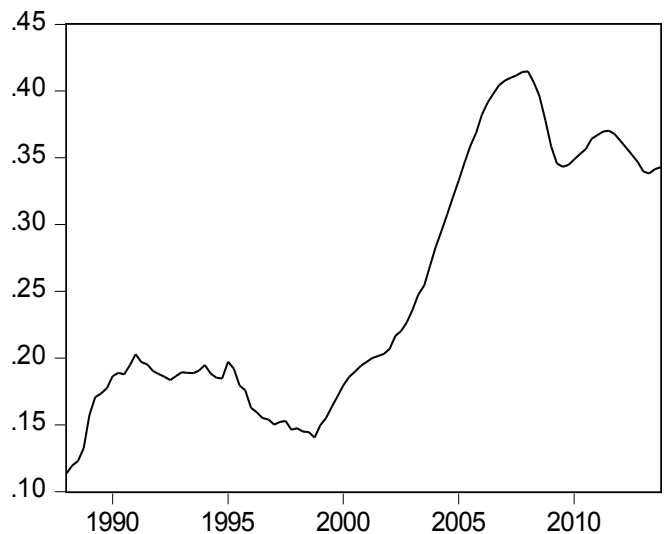

Nominal long term interest rate

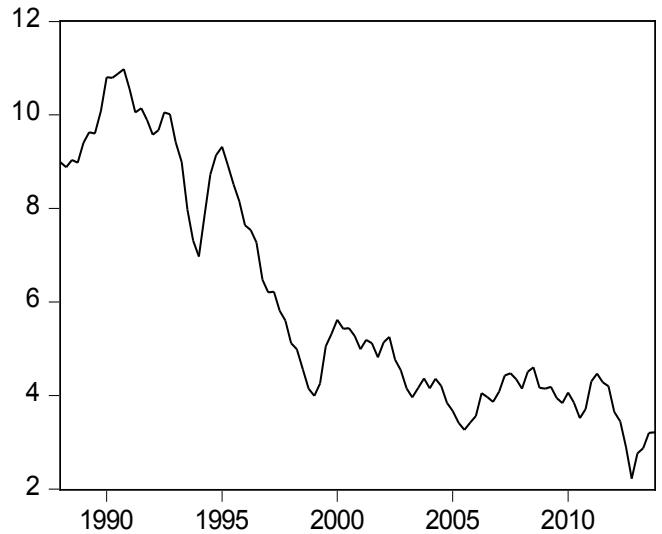

Real income

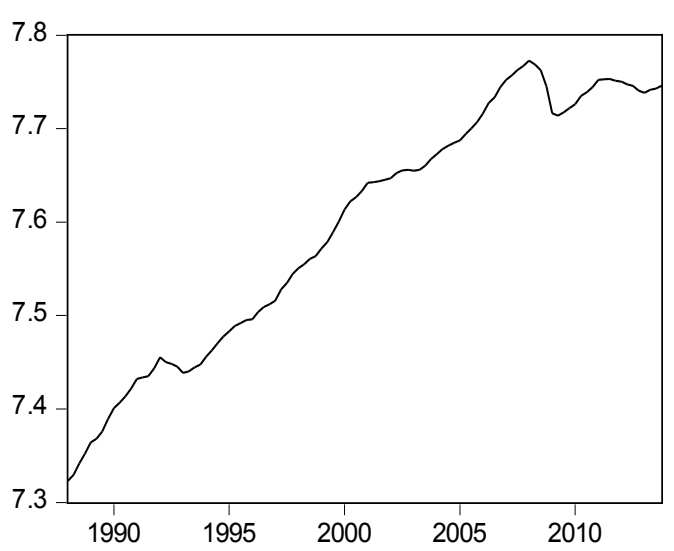

Inflation

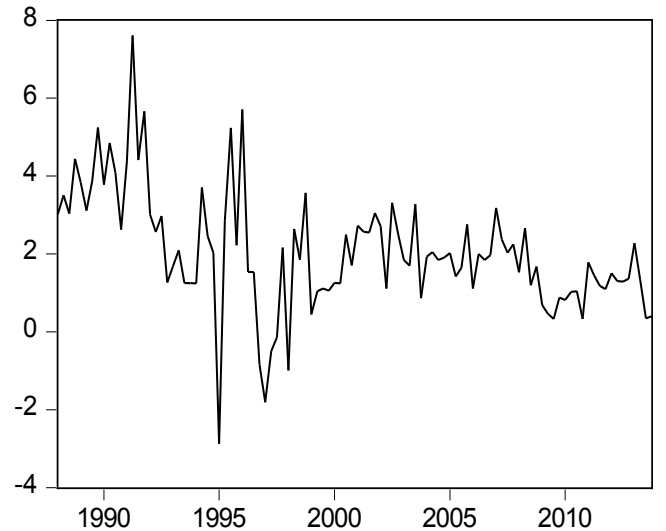

Nominal short term interest rate

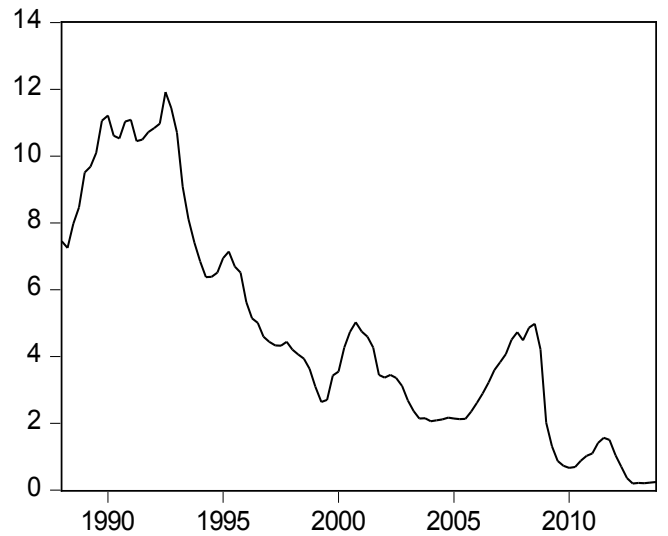

Note: Sample period 1988Q1-2013Q4. 
Figure 2: Mean adjusted deviations from the long run

\section{United States}

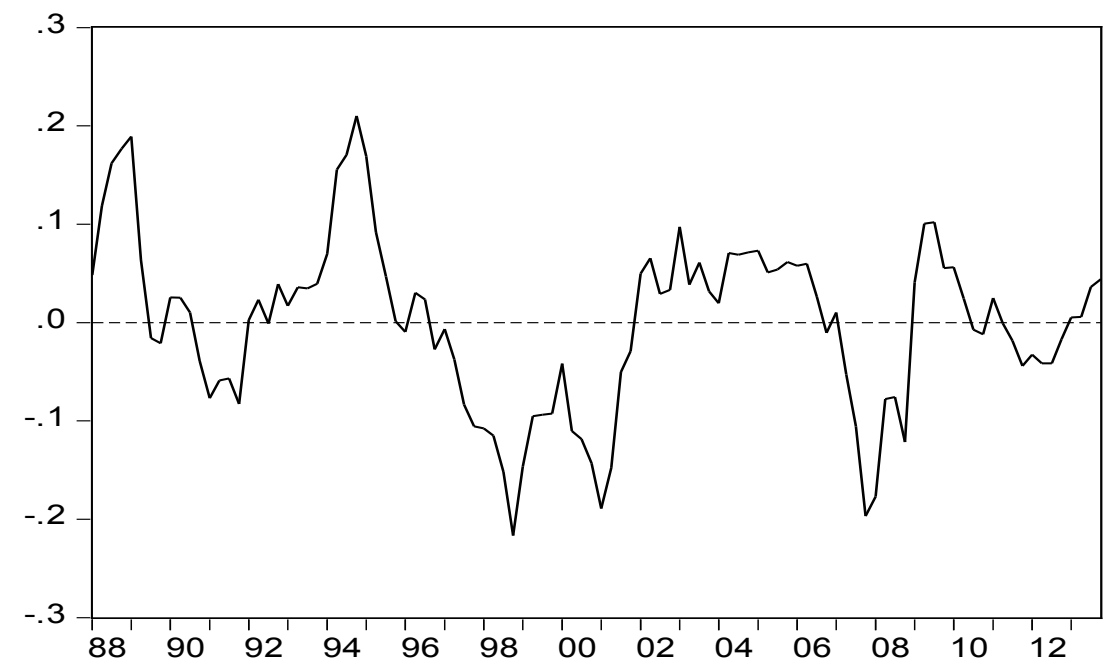

Euro area

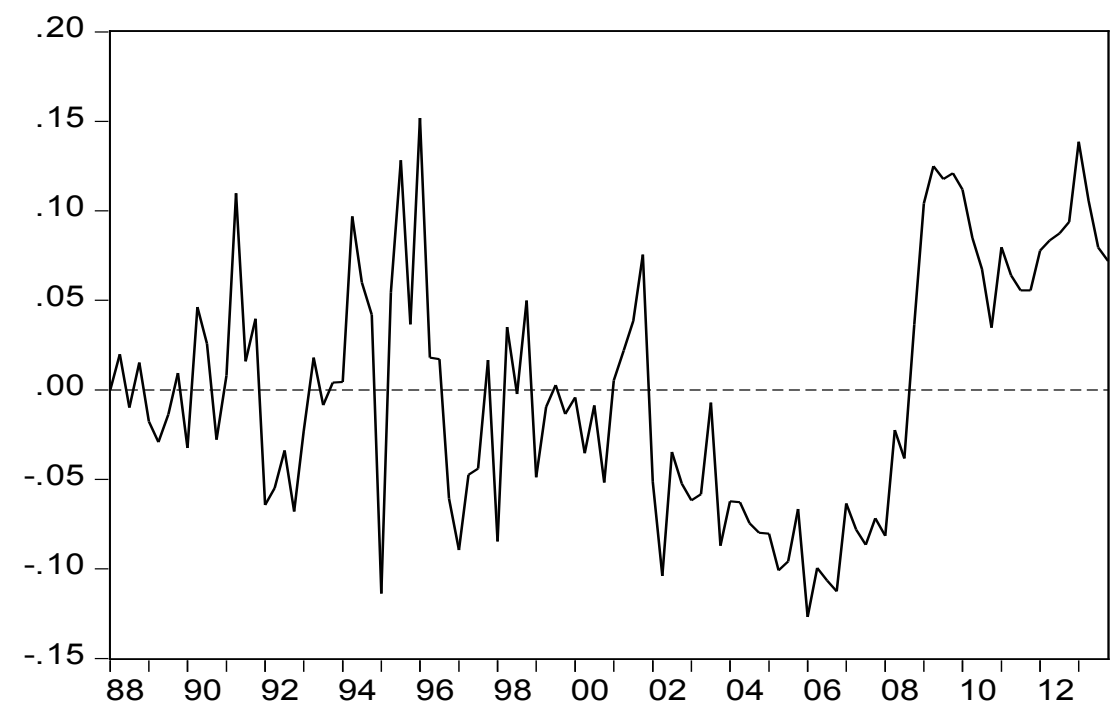

Note: Sample period 1988Q1-2013Q4. Error correction terms correspond to cointegration vector in the single equation approach. 
Figure 3: Cusums of squares of the error correction models

\section{United States}

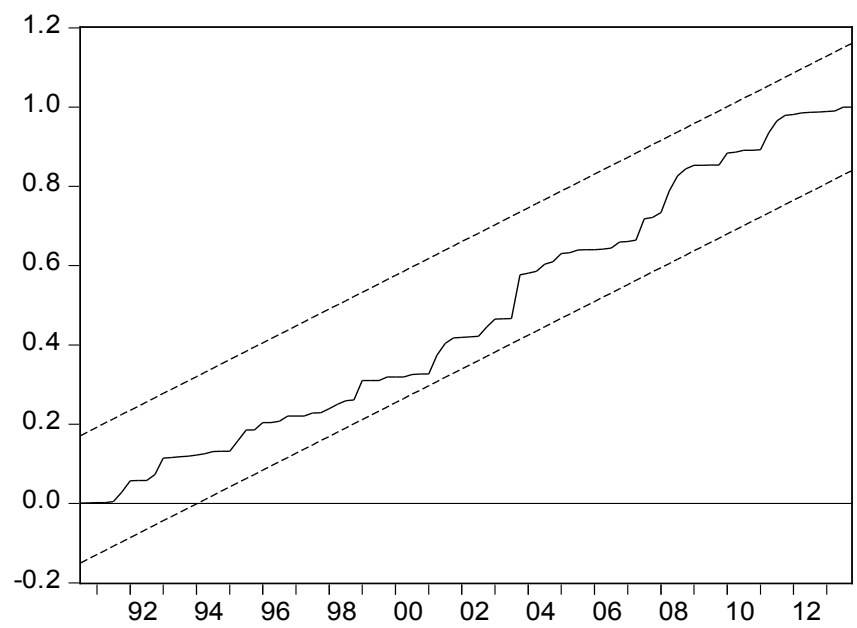

\section{Euro area}

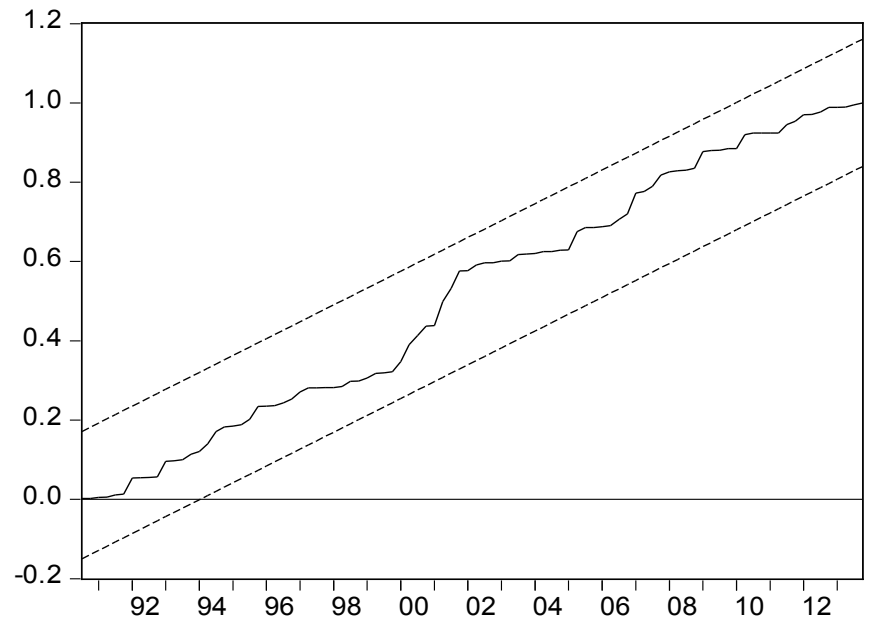

Note: Sample period 1988Q1-2013Q4. Dashed lines represent 0.05 significance levels. 
Table 1

Cointegration rank

\begin{tabular}{|c|c|c|}
\hline & \multicolumn{2}{|c|}{ Trace test } \\
\hline Rank null hypothesis & United States & Euro area \\
\hline 0 & $111.01(0.002)$ & $110.27(0.003)$ \\
1 & $65.59(0.102)$ & $70.25(0.044)$ \\
2 & $35.31(0.437)$ & $46.03(0.072)$ \\
3 & $16.14(0.709)$ & $26.05(0.131)$ \\
4 & $5.49(0.775)$ & $9.76(0.305)$ \\
5 & $0.08(0.778)$ & $1.03(0.310)$ \\
\hline
\end{tabular}

Note: Sample period 1988Q1-2013Q4. Model comprises real money balances, real income, real house prices, long and short term interest rate and the own rate for the US. For the euro area, the same variables are used. Inflation is added, and the own yield is not available. Trace statistic corrected for small sample bias (Johansen, 2002). Models estimated with unrestricted constant. Specifications for the US include the impulse dummies $d 011$ and $d 014$, and for the euro area $d 902$ and $d 011$. The lag order of the underlying VAR model in levels is 2 (BIC) throughout the analysis, $p$-values in parantheses. 
Table 2 Long run money demand and adjustment parameters

\begin{tabular}{|c|c|c|}
\hline & United States & Euro area \\
\hline$m-p$ & 1.000 & 1.000 \\
\hline$y$ & -2.036 & -1.105 \\
\hline$w$ & 0.394 & -1.159 \\
\hline$\pi$ & & 0.003 \\
\hline$R$ & 0.138 & 0.037 \\
\hline$r$ & 0.008 & -0.013 \\
\hline own & -0.152 & \\
\hline$\Delta(m-p)$ & $\begin{array}{c}-0.048 \\
(0.009)\end{array}$ & $\begin{array}{c}-0.099 \\
(0.014)\end{array}$ \\
\hline$\Delta y$ & $\begin{array}{c}0.009 \\
(0.005)\end{array}$ & $\begin{array}{c}-0.003 \\
(0.010)\end{array}$ \\
\hline$\Delta w$ & $\begin{array}{c}0.004 \\
(0.008)\end{array}$ & $\begin{array}{r}-0.005 \\
(0.010)\end{array}$ \\
\hline$\Delta \pi$ & & $\begin{array}{l}5.017 \\
(2.805)\end{array}$ \\
\hline$\Delta R$ & $\begin{array}{c}-0.310 \\
(0.321)\end{array}$ & $\begin{array}{c}-0.460 \\
(0.687)\end{array}$ \\
\hline$\Delta r$ & $\begin{array}{c}0.824 \\
(0.291)\end{array}$ & $\begin{array}{c}-0.217 \\
(0.806)\end{array}$ \\
\hline$\Delta o w n$ & $\begin{array}{c}-0.116 \\
(0.100)\end{array}$ & \\
\hline
\end{tabular}

Note: Sample period 1988Q1-2013Q4. Standard errors are in parentheses. 
Table 3 Conditional error correction model for money demand

\begin{tabular}{|c|c|c|}
\hline & United States & Euro area \\
\hline Constant & $\begin{array}{r}-1.226 \\
(0.231)\end{array}$ & $\begin{array}{l}-0.240 \\
(0.097)\end{array}$ \\
\hline$d 902$ & & $\begin{array}{c}0.029 \\
(0.005)\end{array}$ \\
\hline$d 011$ & $\begin{array}{c}0.023 \\
(0.009)\end{array}$ & $\begin{array}{c}0.027 \\
(0.005)\end{array}$ \\
\hline$d 014$ & $\begin{array}{c}0.023 \\
(0.009)\end{array}$ & \\
\hline$\Delta \pi_{\mathrm{t}}$ & $\begin{array}{r}-0.004 \\
(0.001)\end{array}$ & $\begin{array}{l}-0.003 \\
(0.001)\end{array}$ \\
\hline$(m-p)_{\mathrm{t}-1}$ & $\begin{array}{r}-0.124 \\
(0.018)\end{array}$ & $\begin{array}{l}-0.094 \\
(0.009)\end{array}$ \\
\hline$y_{\mathrm{t}-1}$ & $\begin{array}{c}0.251 \\
(0.036)\end{array}$ & $\begin{array}{l}0.140 \\
(0.019)\end{array}$ \\
\hline$w_{\mathrm{t}-1}$ & $\begin{array}{c}-0.048 \\
(0.013)\end{array}$ & $\begin{array}{l}0.057 \\
(0.007)\end{array}$ \\
\hline$\pi_{\mathrm{t}-1}$ & & $\begin{array}{r}-0.002 \\
(0.001)\end{array}$ \\
\hline$R_{\mathrm{t}-1}$ & $\begin{array}{r}-0.006 \\
(0.002)\end{array}$ & $\begin{array}{l}-0.002 \\
(0.001)\end{array}$ \\
\hline$r_{\mathrm{t}-1}$ & $\begin{array}{r}-0.017 \\
(0.002) \\
\end{array}$ & $\begin{array}{c}0.002 \\
(0.001)\end{array}$ \\
\hline$o w n_{\mathrm{t}-1}$ & $\begin{array}{c}0.031 \\
(0.003)\end{array}$ & \\
\hline$R 2$ & 0.633 & 0.725 \\
\hline
\end{tabular}

Note: Sample period 1988Q1-2013Q4. R2 adjusted R-squared, standard errors in parentheses. 
Table 4: Specification tests of error correction models

\begin{tabular}{|l|c|c|}
\hline & United States & Euro area \\
\hline LM(1) & $2.999(0.087)$ & $1.445(0.232)$ \\
\hline $\operatorname{LM}(4)$ & $1.808(0.134)$ & $2.089(0.089)$ \\
\hline $\operatorname{LM}(8)$ & $1.393(0.211)$ & $1.501(0.169)$ \\
\hline ARCH(1) & $0.725(0.396)$ & $0.083(0.774)$ \\
\hline ARCH(4) & $0.279(0.880)$ & $0.204(0.936)$ \\
\hline JB & $0.176(0.916)$ & $0.925(0.630)$ \\
\hline RESET(1) & $1.661(0.201)$ & $0.550(0.460)$ \\
\hline RESET(2) & $0.918(0.403)$ & $1.022(0.364)$ \\
\hline
\end{tabular}

Note: JB=Jarque-Bera test for normality of the residuals, LM=Lagrange multiplier test for no autocorrelation in the residuals up to specified order, $\mathrm{ARCH}=\mathrm{ARCH}$ test for no conditional heteroscedasticity up to specified order, RESET=Ramsey specification test, $p$-values in parantheses. 
Table 5: Stability tests of error correction models

\begin{tabular}{|l|c|l|}
\hline & United States & Euro area \\
\hline $\mathrm{CF}(07 \mathrm{Q} 1)$ & $1.216(0.254)$ & $0.917(0.589)$ \\
\hline $\mathrm{CF}(08 \mathrm{Q} 1)$ & $1.126(0.341)$ & $0.650(0.881)$ \\
\hline $\mathrm{CF}(09 \mathrm{Q} 1)$ & $0.682(0.831)$ & $0.730(0.783)$ \\
\hline $\mathrm{CF}(10 \mathrm{Q} 1)$ & $0.835(0.643)$ & $0.636(0.845)$ \\
\hline $\mathrm{CF}(11 \mathrm{Q} 1)$ & $0.833(0.616)$ & $0.562(0.866)$ \\
\hline $\mathrm{CF}(12 \mathrm{Q} 1)$ & $0.227(0.987)$ & $0.525(0.835)$ \\
\hline $\mathrm{CF}(13 \mathrm{Q} 1)$ & $0.290(0.884)$ & $0.254(0.907)$ \\
\hline $\mathrm{Max} F$ & $2.443(0.126)$ & $2.700(0.057)$ \\
\hline Exp $F$ & $0.606(0.535)$ & $0.675(0.396)$ \\
\hline Ave $F$ & $1.147(0.265)$ & $1.275(0.156)$ \\
\hline N & & \\
\hline
\end{tabular}

Note: $\mathrm{CF}=\mathrm{Chow}$ forecast test for no structural break at specified period, Max $F$, Exp $F$, Ave $F$ QuandtAndrews Test (LR) for no structural break with unknown break point, where a trimming parameter of 10 percent is applied. $p$-values in parantheses. 